\title{
Insights into Sheep Genetic Improvement Practices Through Crossbreeding in Ethiopia: Achievements, Challenges and Future Prospects
}

\author{
Abiye Shenkut Abebe ${ }^{1^{*}} \quad$ Kefyalew Alemayehu ${ }^{2}$ \\ 1.Department of Animal Science, Debre Tabor University, P.O.Box 272, Ethiopia \\ 2.Department of Animal Production and Technology, Bahir Dar University, Ethiopia
}

\begin{abstract}
Crossbreeding is one of the genetic improvement methods that enables to utilize between breed genetic variations. It is one of the main sheep genetic improvement strategies practiced for decades in Ethiopia. This review assessed achievements, challenges and future prospects of sheep genetic improvement through crossbreeding in Ethiopia. The crossbreeding scheme involves crossing of exotic breeds with indigenous as well as between indigenous sheep breeds. To improve growth performance of indigenous sheep, a number of exotic sheep breeds were imported from abroad although literature sources about the performance of crossbreeds is available only for Awassi and Dorper sheep crosses. Promising results have been reported in few areas where crossbreeding has been performed effectively. An evidence for this is the realization of up to $10 \mathrm{~kg}$ yearling live weight superiority of crossbreeds with $50 \%$ and above Awassi and Dorper sheep blood levels over the indigenous sheep. As a national genetic improvement strategy, however, crossbreeding achievement in terms of improving productivity of indigenous sheep is generally minimal. Notably, Absence of well-deigned crossbreeding program, miss-match between genotypes and the environment, and resource limitation to maintain and multiply adequate number of exotic sheep and crossbreeds are the major challenges hindering the success of indigenous sheep genetic improvement through crossbreeding. In the future, the use of crossbreeding as a potential strategy for indigenous sheep genetic improvement relies on bringing long lasting solutions to the current problems. In general, implementing well-designed crossbreeding program, particularly between improved exotic sheep and indigenous sheep, should be the primary focus to improve productivity of indigenous sheep. In this way, the contribution of indigenous sheep resources for the smallholder farmers in particular and the country's economic growth in general can be maximized. At the same time, protecting the valuable genetic resources of indigenous sheep should be an integral part of the crossbreeding program.
\end{abstract}

Keywords: genetic improvement, indigenous sheep of Ethiopia, sheep crossbreeding

DOI: $10.7176 /$ ALST/75-01

Publication date:June $30^{\text {th }} 2019$

\section{INTRODUCTION}

Crossbreeding is one of the genetic improvement methods that helps to combine desired parental characteristics into their offspring. Particularly when there is significant genetic variation between breeds for the trait of interest, crossbreeding could result in fast genetic improvement due to the additive and non-additive genetic effects (Schoeman, 2000; Baker and Gray, 2004). The parental breeding values inherited by their offspring correspond to the additive genetic effects while interaction of alleles at the same locus or different loci is related with nonadditive genetic components, which is commonly called Heterosis. It is in this way that the crossbreed offspring perform higher than the average performance of their parents. Crossbreeding is also important for new breed formation. Through a review of new breed development efforts in different countries, Shrestha (2005) reported about 443 composite sheep breeds developed by crossbreeding of two and more breeds in 68 countries.

In the tropics where resource is very limited to undergo selective breeding, crossbreeding has been the main sheep genetic improvement strategy although results are largely unsatisfactory (Kosgey et al., 2006; Philipsson et al., 2011). The situation is very similar in Ethiopia where sheep crossbreeding between indigenous breeds and/or indigenous with improved exotic breeds have been practiced for many years with achievements far below the expectations. The reasons are largely related with lack of implementation strategies. Ethiopian indigenous sheep are generally slow in growth performance with average yearling weight of about $20 \mathrm{~kg}$ and dressing percentage of below 50\% (Gizaw et al., 2013; Mekuriaw et al., 2013; Tilahun et al., 2014; Gulilat et al., 2018). The crossbreeding strategy was thought to address such issue. Subsequently, a number of improved exotic sheep were imported from different countries for the purpose of crossbreeding. In addition to exotic sires, local breed rams such as Washera, Bonga and Horro have been widely distributed for interbreeding with other relatively small sized indigenous sheep (Taye et al., 2011; Mekuriaw et al., 2013; Alayu et al., 2014; Lemma et al., 2014). In spite of the crossbreeding efforts made for decades, average sheep productivity is still the lowest in the world. Furthermore, the current proportion of crossbreed sheep population is negligible, which is about $0.32 \%$ (CSA, 2016). 
Despite its lack of effectiveness at the national level, sheep crossbreeding based on both exotic and indigenous sires have been continuing for different indigenous sheep breeds. Thus, critically assessing the current sheep crossbreeding practices, achievements and associated challenges including the benefits provided for the smallholders could be useful to generate information as inputs for policy makers and other concerned bodies for designing effective and sustainable crossbreeding program in the future. As such, this review aimed at assessing sheep crossbreeding practices for a wider insight into the achievements, challenges and future prospects in Ethiopia.

\section{OVERVIEW OF SHEEP CROSSBREEDING PRACTICES IN ETHIOPIA}

In Ethiopia, importation of exotic sheep breeds started as early as 1944 when Merino rams brought from Italy by humanitarian organization (Markos, 2006). Later on, multiple exotic breeds such as Corriedale, Hampshire, Romney Marsh, Blue De Maine and Rambouillet have been imported from different countries (Markos, 2006). Awassi from Israel and Dorper from South Africa are the recently introduced exotic sheep breeds in Ethiopia (Gizaw et al., 2013). Following importation, evaluation and multiplication of crossbreeds with different exotic blood level have been carried out in different agricultural research institutes and government ranches. Then, high-grade crossbreed rams have been distributed in different parts of the country for crossbreeding with the indigenous sheep. Among the introduced exotic breeds, however, information about the performance of crossbreeds is available only for Awassi and Dorper sheep. The occurrence of disease outbreak and lack of welldesigned ram distribution strategies are reported to be the principal factors that contributed for the anonymity of other exotic breeds (Gizaw et al., 2013).

Average growth performance of indigenous sheep is very low compared with Dorper and Awassi exotic sheep in their native areas. As shown in Table 1, Dorper sheep in South Africa is more than three times heavier than Ethiopian Menz and Farta indigenous sheep breeds at about similar age group. Similarly, a six month old improved Awassi sheep in Turkey weighs higher than a yearling Ethiopian Bonga indigenous sheep. Given such facts, the major target of implementing crossbreeding between imported exotic breeds and indigenous sheep was improving growth performances of indigenous sheep (Gizaw et al., 2013). The fact that indigenous sheep are the result of natural selection and geographical isolation, they are assumed to retain genes playing vital roles for environmental adaptation. Thus, crossing of indigenous sheep with improved exotic sheep make sense biologically to exploit the advantage of breed complementary. Subsequently, smallholders engaged in sheep rearing could earn better income by selling crossbreed lambs with fast growth performance at a better price thereby empowers the efforts made to create food self-sufficiency. Currently, crossbreeding is continuing although achievements are unattractive due to different challenges.

Table 1. Yearling weight of some indigenous sheep compared to exotic breeds

\begin{tabular}{lll}
\hline Breeds* & $\begin{array}{l}\text { Average yearling weight } \\
(\mathrm{kg}+\mathrm{SE})\end{array}$ & Sources \\
\hline Menz & $20.07 \pm 0.48$ & Lemma et al., 2014 \\
Afar & $26.6 \pm 0.14$ & Yibrah, 2008 \\
Farta & $20.08 \pm 0.73$ & Mekuriaw et al., 2013 \\
Wello & $21.6 \pm 1.00$ & Amare et al., 2018 \\
Gumz & $23.05 \pm 0.645$ & Solomon, 2007 \\
Horro & $19.7 \pm 0.63$ & Kassahun, 2000 \\
Washera & $24.70 \pm 1.13$ & Mekuriaw et al., 2013 \\
Bonga & $28.69 \pm 0.48$ & Zewdu, 2008 \\
Blackhead Somali & 25.7 & Bireda et al., 2016 \\
Dorper (South Africa) & $64.4 \pm 1.1$ & Snyman and Olivier, 2002 \\
Dorper (Romania) & $55 \pm 0.89$ & Gavojdian et al., 2013 \\
Dorper (Ethiopia) & $34.43 \pm 0.79$ & Abebe et al., 2015 \\
Awassi (Turkey) & 37 (in 6 month) & Dikmen et al., 2007
\end{tabular}

*All except Dorper and Awassi sheep are indigenous to Ethiopia

\section{ACHIEVEMENTS OF SHEEP CROSSBREEDING IN ETHIOPIA}

Achievements in sheep crossbreeding can be assessed from two perspectives. The first one is the level of genetic improvement for the traits of interest on indigenous sheep while the second is related with the contribution of genetic improvement following crossbreeding to livelihood development of the smallholder farmers.

\subsection{Achievements in growth performance traits}

So far, growth performances of some of the crossbreed sheep have been evaluated both under improved and traditional management practices (Gizaw and Getachew, 2009; Mekuriaw et al., 2013; Lakew et al., 2014; Tilahun et al., 2014; Lemma et al., 2014; Teklebrhan et al., 2016). Improved management refers to the 
husbandry practice implemented in research farms with better health care and feed provision while the traditional management is the low-input system practiced at smallholder level. To compare growth performances of crossbreeds with pure indigenous sheep, weight at birth, 3 months (weaning age) and 12 months (yearling age) are presented in Table 2.

Awassi exotic sheep have been largely crossed with Menz, Wello and Tikur indigenous sheep. Based on the information in Table 2, regardless of Awassi's sheep blood level, crossbreeds have higher body weight at different growth periods compared to the local indigenous sheep. For example, under improved management practice, the indigenous Menz sheep have birth and weaning weight of about 1.96 and $7.82 \mathrm{~kg}$, respectively while its $50 \%$ Awassi crossbreeds weighed about $2.53 \mathrm{~kg}$ at birth and $16.84 \mathrm{~kg}$ at weaning age under similar rearing system. Interestingly, introgression of as little as less than a quarter of Awassi's sheep blood level into indigenous sheep through crossbreeding have resulted in a reasonable amount of body weight improvement (Table 2). Furthermore, when the amount of Awassi sheep blood level increases, crossbreeds perform much better than indigenous local sheep even under farmers' management practices (Figure 1). Based on the results depicted in Figure 1, crossbreeds with 50\% and above Awassi's sheep genotypes have shown the highest weights recorded from birth to yearling ages than indigenous sheep and low grade Awassi genotypes. For example, an average of $10 \mathrm{~kg}$ live weight difference observed between high grade Awassi crossbreeds and indigenous sheep at yearling age.

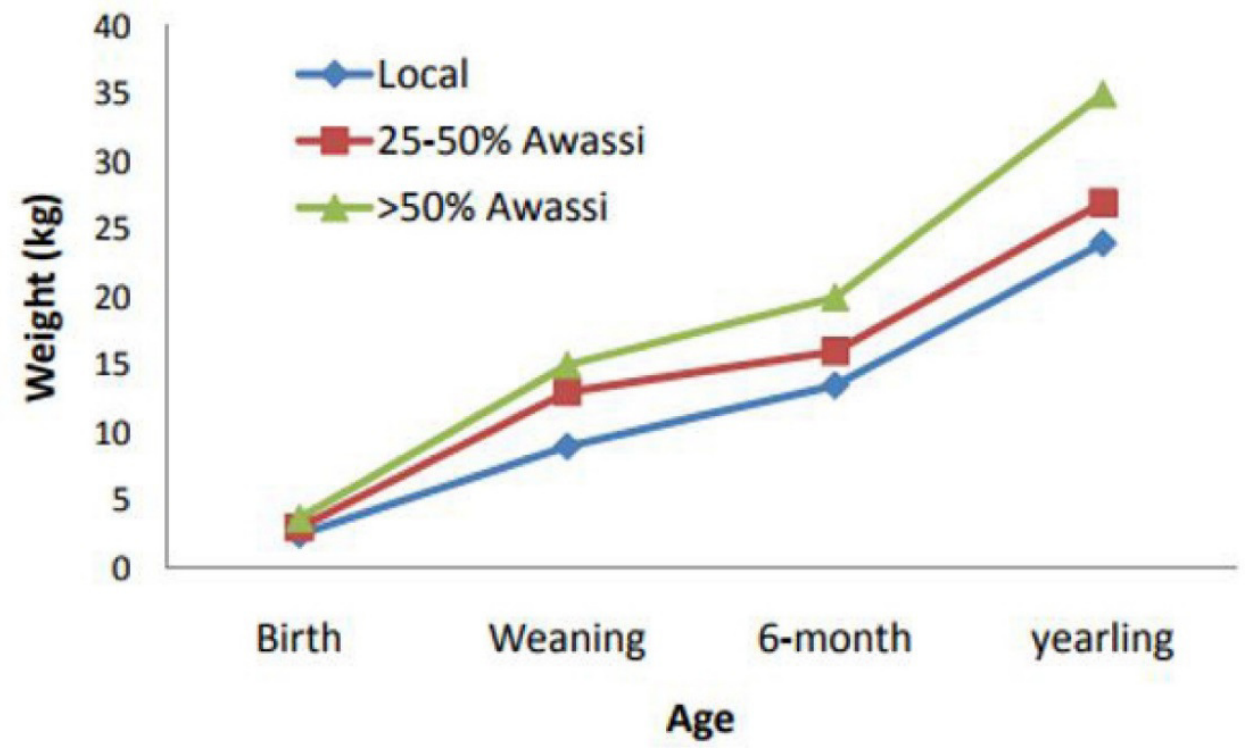

Figure 1. Growth rate of local sheep and their crosses with Awassi exotic sheep under village management conditions in Ethiopia (Source: Gizaw and Getachew, 2009)

In addition to Awassi with indigenous sheep crossbreeding, the South African Dorper sheep have been crossed with different Ethiopian indigenous sheep breeds. As shown in Table 2, crossbreeds with 50\% Dorper genotype are superior at birth, weaning and yearling ages as compared to indigenous Menz and Wello sheep that have been used as dam sources for crossbreeding. Characteristically, Dorper sheep are hairy type of breed that are suitable for medium to lowland agroecology but are also known to have wide ecological adaptation which can be evidenced by the superiority of Dorper crossbreeds when crossbred with Menz indigenous sheep reared in cool highland areas. Given the fast growth rate and wide adaptation potential of Dorper sheep (Snyman and Olivier, 2002), implementing well designed crossbreeding between Dorper and Ethiopian indigenous sheep could play decisive roles in improving the productivity of the latter. 
Table 2. Growth performance of crossbreeds compared to pure indigenous sheep with standard error (SE)

\begin{tabular}{|c|c|c|c|c|c|}
\hline Genotypes*+ & Management & $\begin{array}{l}\text { Birth } \\
\text { weight } \\
(\mathrm{kg} \pm \mathrm{SE})\end{array}$ & $\begin{array}{l}\text { Weaning weight } \\
(\mathrm{kg} \pm \mathrm{SE})\end{array}$ & $\begin{array}{l}\text { yearling } \\
\text { weight } \\
(\mathrm{kg} \pm \mathrm{SE})\end{array}$ & Sources \\
\hline 37.5\%Awassi X Menz & Traditional & 3.35 & 10.47 & $\begin{array}{l}15.28(6 \\
\text { month })\end{array}$ & Hasan et al., 2002 \\
\hline Pure Menz sheep & Improved & $1.96 \pm 0.03$ & $7.82 \pm 0.16$ & $20.07 \pm 0.48$ & Lemma et al., 2014 \\
\hline Awassi X Menz & Improved & 2.53 & 16.84 & - & Hasan et al., 2004 \\
\hline 75\% Awassi X Menz & Improved & 3.32 & 18.89 & - & Hasan et al., 2004 \\
\hline $\begin{array}{l}23.44 \% \% \text { Awassi X } \\
\text { Tikur sheep }\end{array}$ & Traditional & $3.10 \pm 0.10$ & $12.01 \pm 0.32$ & $24.16 \pm 0.54$ & Tilahun et al., 2016 \\
\hline $\begin{array}{l}32.5 \% \text { Awassi X Tikur } \\
\text { sheep }\end{array}$ & Traditional & $3.08 \pm 0.03$ & $12.56 \pm 0.25$ & $25.65 \pm 0.45$ & Tilahun et al., 2016 \\
\hline Dorper X Wello sheep & Improved & $3.24 \pm 0.04$ & $14.95 \pm 0.21$ & $31.37 \pm 0.38$ & Lakew et al., 2014 \\
\hline Pure Wello sheep & Traditional & $1.90 \pm 0.04$ & $10.70 \pm 0.60$ & $21.60 \pm 1.00$ & Amare et al., 2018 \\
\hline Dorper X Bonga sheep & Improved & $2.62 \pm 0.19$ & $13.90 \pm .85$ & $\begin{array}{l}20.97 \pm 2.6(6 \\
\text { month })\end{array}$ & $\begin{array}{l}\text { H/Giorgis et al. } \\
2017\end{array}$ \\
\hline $\begin{array}{l}\text { Dorper X Blackhead } \\
\text { Somali }\end{array}$ & Improved & $3.10 \pm 0.10$ & $15.10 \pm 0.30$ & - & $\begin{array}{l}\text { Teklebrhan et al., } \\
2014\end{array}$ \\
\hline Dorper X Menz & Improved & $2.77 \pm 0.04$ & $13.34 \pm 0.25$ & $31.33 \pm 0.56$ & Abebe et al., 2015 \\
\hline Pure Washera sheep & Traditional & $2.61+0.00$ & $12.78 \pm 0.45$ & $24.70 \pm 1.13$ & $\begin{array}{l}\text { Mekuriaw et al., } \\
2013\end{array}$ \\
\hline WasheraX Farta & Traditional & $2.59+0.02$ & $11.17 \pm 0.49$ & $22.50 \pm 1.56$ & $\begin{array}{l}\text { Mekuriaw et al., } \\
2013\end{array}$ \\
\hline Pure Farta sheep & Traditional & $2.50+0.01$ & $9.94 \pm 0.74$ & $20.08 \pm 0.73$ & $\begin{array}{l}\text { Mekuriaw et al., } \\
2013\end{array}$ \\
\hline Washera X Menz & Improved & $2.02+0.03$ & $8.01 \pm 0.16$ & $19.93 \pm 0.49$ & Lemma et al., 2014 \\
\hline Bonga X Menz & Improved & $2.05+0.03$ & $8.30 \pm 0.16$ & $21.73 \pm 0.53$ & Lemma et al., 2014 \\
\hline 75\%Washera X Menz & Improved & $2.33+0.04$ & $9.10 \pm 0.25$ & $17.20 \pm 0.82$ & Lemma et al., 2014 \\
\hline 75\%Bonga X Menz & Improved & $2.46+0.05$ & $10.80 \pm 0.27$ & $20.40 \pm 0.78$ & Lemma et al., 2014 \\
\hline
\end{tabular}

* All except Dorper and Awassi sheep are indigenous to Ethiopia.

${ }^{+}$Crossbreed's genotype is 50\% unless the genotype is given. E.g. Dorper $X$ Wello sheep genotype means crossbreeds with 50\% Dorper \& 50\%Wello sheep while 37.5\% Awassi X Menz genotype means crossbreeds with $37.5 \%$ Awassi \& $62.5 \%$ Menz sheep blood level.

Given the difficulties of importing, multiplying and maintaining exotic sheep due to resource limitation, between indigenous sheep crossbreeding has been tried. For instance, crossbreeding between Washera X Menz, Washera X Farta and Bong X Menz sheep have been performed (Mekuriaw et al., 2013; Lemma et al., 2014). Crossbreeding between indigenous breeds has a number of advantageous when compared with crossbreeding of indigenous sheep with exotic breeds. For example, it does not require importations of exotic breeds, maintaining of pure exotic breeds, continuous multiplication and distribution of cross breeds. Furthermore, not only most indigenous sheep are found geographical in close proximity but also the farming communities share a number of sociocultural characteristics that make crossbreeding between indigenous sheep as an ideal strategy in principle to improve sheep productivity.

However, performance variation between indigenous sheep is small, thus performances of crossbreeds are not better than parents. Performance of crossbreeds obtained from two indigenous sheep breeds is displayed in Table 2, showing that crossbreeding between indigenous sheep with the current performance level of the local sheep is not logical. A better option could be applying selective breeding for indigenous sheep genetic improvement for certain generations and trying crossbreeding later. Studies conducted so far have shown that indigenous sheep have high within population genetic diversity than the between population showing their potential for improvement through selective breeding instead of crossbreeding (Gizaw et al., 2007; Helen, 2015).

\subsection{Contribution to smallholders' livelihood development}

So far, no adequate impact assessments have been made to disentangle the contribution of sheep crossbreeding for livelihood development of smallholder farmers in Ethiopia. However, Tefera et al. (2014) evaluated diffusion rate and financial gain of Awassi X Menz sheep crossbreeding in model villages and reported that the composition of crossbreeds in the sampled flock is nearly equal with that of the indigenous sheep. These authors argued that the number of crossbreeds and local indigenous sheep would not be balanced in the flock of a farmer unless s/he credited the importance of crossbreeding. The same authors also mentioned that farmers fetch better price for crossbreeds over the locals and were able to accumulate reasonable amount of asset by selling 
crossbreed lambs. It has been reported that breeder farmers have been created to produce genetic material with high grade Awassi crossbreeds that can be supplied to other areas (Gizaw and Getachew, 2009). Such practices, however, are concentrated in few villages where farmers carryout crossbreeding with better understanding through continuous support from government institutes.

Scholars have been arguing that despite the long period practices of sheep crossbreeding in the country, its impact on the livelihood of smallholders is generally insignificant. Explicitly, the existing facts about Ethiopian indigenous sheep current productivity could not reflect the existence of crossbreeding based genetic improvement efforts made for more than half a century. For example, population size of crossbreed sheep is below $1 \%$ of the total sheep resources of the country (CSA), 2016). Furthermore, national average productivity of indigenous sheep is still very low and well below commercial market requirements (CSA, 2016). Considering such facts, the contribution of sheep crossbreeding on livelihood development of smallholder farmers who have been involving in sheep rearing is nowhere near what has been anticipated except the success stories in a very limited villages involving small number of farmers. There are, however, a number of challenges that are assumed to contribute to the vain achievements of sheep crossbreeding in Ethiopia.

\section{CHALLENGES OF SHEEP CROSSBREEDING PRACTICES IN ETHIOPIA}

One of the major obstacles hindering effectiveness of crossbreeding strategy in Ethiopia is the absence of clear crossbreeding program supported by policy and implementation strategies. As a result, specialized exotic breeds imported with high cost or sometimes through foreign aids have been crossed with indigenous breeds indiscriminately. Often for long period, crossbreed rams with high grade exotic blood level have been distributed to smallholder farmers as a campaign without establishing recording system in the production environment (Gizaw et al., 2013). Subsequently, most of the imported exotic breeds became anonymous over time. At present, information or literatures about the performance of crossbreeds is available only for Awassi and Dorper sheep where the latter imported lately.

Another challenge is that exotic breeds have been developed in different environment than that of the Ethiopia condition. Although crossbreeding is expected to combine the genes responsible for better growth from exotic breeds and adaptation merits from the indigenous sheep, the existing low-input production system of the country significantly undermined expression of the genotypic potentials. This has been typical phenomena in Ethiopia where crossbreed sheep failed to express their potentials due to miss-match between genotypes and the environment especially when the genetic material of exotic breeds has been increased. Furthermore, the nongenetic components, such as feed and health aspects, were not integrated in the crossbreeding practice while using highly productive exotic sheep. In such scenario, addressing larger areas of the country for wider scale sheep genetic improvement through crossbreeding could be difficult.

A Further headache is that exotic sire based crossbreeding requires frequent importations and maintaining of pure exotic breeds, and continuous multiplication and distribution of cross breeds (Gizaw and Getachew, 2009; Gizaw et al., 2013). This could be a huge burden for resource poor country like Ethiopia. As an option to exotic sire based crossbreeding, between indigenous sheep crossbreeding have been tried (Taye et al., 2011; Mekuriaw et al., 2013; Lemma et al., 2014). However, such scheme has faced two challenges. First, performance difference among indigenous sheep breed for economically important traits such as growth is quite small, thus genetic improvement following crossbreeding has not been attractive. Second, none of the indigenous sheep breeds has been developed for a specific purpose instead evolved through natural selection and largely merited for adaptation to low-input production environments. Thus, genes controlling economically important traits may not adequately be expressed as a result crossbreeding exerts little effect on quantitative traits.

In general, ineffectiveness of sheep crossbreeding in Ethiopia is known to be associated with multilateral factors that encompass technical, financial and institutional issues. Such issues have to be clearly sorted out and adequately addressed in the genetic improvement program in the future. If planned well and implemented accordingly, the exotic sire based crossbreeding strategy has the potential to improve indigenous sheep productivity adequately and thereby maximize their contribution for livelihood development of the community in particular and the country's economic growth in the broader context.

\section{FUTURE PROSPECTS OF SHEEP CROSSBREEDING IN ETHIOPIA}

Ethiopia has huge sheep genetic resources numbering at about 30.7 million heads of which $99.72 \%$ are indigenous type (CSA, 2016). Average productivity of sheep, however, is one of the lowest in the world. Despite the poor productivity of indigenous sheep, they are known to provide diverse functions such as income and food sources for the smallholder farmers in the country. The fact that food insecurity and poverty are chronic problems particularly at smallholder level, improving productivity of indigenous sheep could be a good pathway to bring long-lasting solutions for such nagging challenges. Although attempts have been made to improve genetic performances of indigenous sheep through crossbreeding, achievements are far below the expectations due to the summed up effects of multiple factors. Thus, learning adequate lesson from past failure is crucial to 
plan effective crossbreeding strategy for sustainable genetic improvement in Ethiopian indigenous sheep.

\subsection{Exotic sheep breed based crossbreeding}

Exotic sheep in this article is to refer to those improved through selective breeding for economically important traits in their native area and imported to Ethiopia for crossbreeding with indigenous sheep. Typical examples are the Israeli's Awassi and South African hairy Dorper sheep that are already imported and used for crossbreeding purpose in Ethiopia. The Ethiopian indigenous sheep are not subjected to systematic selection for a particular trait instead developed through natural selection to survive and reproduce in low-input and stressful production environment. Way of combining the good adaptive potential of indigenous sheep with the high productive capacity of improved breed is through crossbreeding. Biologically, it can be considered as the optimal way to make productivity of indigenous sheep better off.

Following selection of the genetic improvement strategy, the next step is devising ways of implementation based on interests of the target beneficiaries and communities. Implementing genetic improvement program requires clear understanding of both the genetic and non-genetic components beyond the theoretical consideration, which are key determinants for the success of any breeding program (Baker and Gray, 2004; Kosgey et al., 2008). One of the issues that detracts the success of exotic sheep based crossbreeding that has been conducted for long time in Ethiopia is the inability of crossbreed lambs to express their full potential under traditional management system. In other words, the existing husbandry practices do not support highly productive sheep implying improvement on the management condition should be performed with similar magnitude like that of the genetic component. Thus, matching the crossbreeds' genotype with the production environment is fundamental to achieve goals through exotic sheep based crossbreeding.

\subsection{Setting clear crossbreeding goal}

Crossbreeding can be used to develop synthetic breed, substitute less performing breed with superior breeds over time or upgrade to a certain level of the genetic make-up of the favored parent into the crossbreed offspring (Baker and Gray, 2004; Shrestha, 2005; Philipsson et al., 2011). However, achieving such targets could require different procedure implying that the goal of crossbreeding should be clearly defined. From Ethiopian indigenous sheep perspectives, upgrading of crossbreeds to appropriate exotic blood level seems promising. Introgression of exotic blood level ranging from half to a three-quarter is reported to be effective for Ethiopian indigenous sheep in terms of improving growth performance (Gizaw and Getachew, 2009; Lemma et al., 2014, Teklebrhan et al., 2014; H/Giorgis et al., 2017). Thus, designing systems that enable to use the appropriate crossbreed genotypes at wider scale will have paramount importance in achieving the target goal.

Synthetic breed formation could also be reasonably applicable in Ethiopian condition though no previous attempt has been made. Globally, a number of synthetic sheep breeds haven developed through crossbreeding method. The best examples for synthetic breed formation through crossbreeding are the development of Dorper in South Africa (Cloetea et al., 2000) and Assaf sheep in Israel (Pollitt and Gootwine, 2004). Dorper is a hardy, early maturing and fast grower South African composite breed developed from a cross between the Blackheaded Persian and the Dorset Horn sheep. The Assaf dairy sheep, on the other hand, have been originated from a cross involving improved Awassi and East Friesian sheep breeds. Considering such achievements, new breed formation from a cross between the preferred exotic sheep and selected Ethiopian indigenous sheep could be realistic. In this regard, establishing crossbreed sheep breeders cooperative at smallholder level could be a good entry point for synthetic breed formation. Furthermore, synthetic breed formation could eliminate the constraints associated with maintaining of pure exotic breeds.

\subsection{Prevent crossbreeding from becoming a threat for genetic resource}

Crossbreeding has to be implemented to wider scale to address large smallholder farmers who own indigenous sheep. However, due consideration should be given to prevent valuable genes of indigenous sheep from becoming victims of extinctions by genes from exotic breed. In this regard, establishing indigenous sheep genetic resource conservation program is needed. Conservation of all indigenous sheep breeds may not be feasible under the current situation in Ethiopia, for instance, due to resource limitation. Thus, breed prioritization for conservation and delineating crossbreeding areas should be integral parts of the crossbreeding based genetic improvement program. In general, genetic improvement should not be at the expense of the genetic resource of indigenous sheep of the country.

\section{CONCLUSIONS}

To improve growth performance of Ethiopian indigenous sheep, crossbreeding between exotic and indigenous as well as between indigenous sheep breeds have been practiced for longer period. From the crossbreeding attempts made so far, promising achievements have been reported in few areas where crossbreeding has been performed effectively. A typical example is the realization of up to $10 \mathrm{~kg}$ yearling live weight superiority of high grade 
Awassi crossbreeds over the indigenous sheep. As a national genetic improvement strategy, however, achievements of crossbreeding in terms of improving productivity of indigenous sheep are generally minimal. Technical and financial resource limitations and poor institutional setup of the livestock sector are the core problems that constrained the success of sheep crossbreeding in the country. In the future, the use of crossbreeding as a potential tool for indigenous sheep genetic improvement lies in bringing long lasting solutions to the current problems. In general, implementing well-designed crossbreeding program, particularly between improved exotic sheep and indigenous sheep, should be the primary focus to improve productivity of indigenous sheep. In this way, the contribution of indigenous sheep resources for the smallholder farmers in particular and the country's economic growth in general can be maximized.

\section{REFERENCES}

Abebe, A., Gizaw S., Bisrat, A, Goshme, S., Besufekad, S., Mekonen, T., Zewdie, T. and Chanyalew, Y. (2015). Growth Performance of Dorper and its F1 Crossbreds at Debre Birhan Agricultural Research Center. Developing Country Studies. 5, 90-98.

Alayu, K., Surafel, M., Solomon, A., Alemu, T. and Temesgen, T. (2014). Assessment of the Performance of Washera Rams Distributed and Farmers' Perception in North Gondar Zone, Amhara Region. Pages 34-43 in Proc. $6^{\text {th }}$ and $7^{\text {th }}$ Amhara Agricultural Research Institute Annual Regional Conference on Livestock Completed Research Activities, Bahir Dar, Ethiopia.

Amare, T., Goshu, G. and Tamir, B. (2018). Lamb Growth Performance Evaluation of Wollo Highland Sheep and Their F1 Crossbreds on Smallholder farm in South Wollo, Ethiopia. Middle-East J. Sci. Res. 26, 35-45.

Baker R.L. and Gray G.D. (2004). Appropriate breeds and breeding schemes for sheep and goats in the tropics: Worm Control for Small Ruminants in Tropical Asia, Australian Centre for International Agricultural Research (ACIAR) Series No.113. Pages 63-96.

Teferra, B., Bizuayehu, S. and Abebe, A. (2014). Diffusion and Financial Evaluation of Improved Awassi- Menz Crossbred Sheep in North Shewa and South Wello, Amhara Region. Pages 92-107 in Proc. 6th and 7th Amhara Agricultural Research Institute Annual Regional Conference on Livestock Completed Research Activities, Bahir Dar, Ethiopia.

Bireda, W., Kebede, K., Mekashaw, Y. and Bejano, S. (2016). Phenotypic Characterization of Black Head Somali Sheep in Gode and Adadile Districts, Ethiopia. Global Veterinaria. 17, 265-270.

Cloetea, S.W.P., Snyman, M.A. and Herselman, M.J. (2000). Productive performance of Dorper sheep. Small Ruminant Research. 36, 119-135.

CSA (Central Statistical Agency). (2016). Agricultural Sample Survey 2016/17. Volume II report on livestock and livestock characteristics (private peasant holdings). Statistical bulletin 585, Addis Ababa, Ethiopia.

Dikmen, S., Turkmen, I., Ustuner, H., Alpay, F., Balci, F., Petek, M., and Ogan, M. (2007). Effect of weaning system on lamb growth and commercial milk production of Awassi dairy sheep. Czech Journal of Animal Sciences. 52, 70-76.

Gavojdian, D., Cziszter, L.T., Pacala1, N. and Sauer, M. (2013). Productive and reproductive performance of Dorper and its crossbreds under a Romanian semi-intensive management system. South African Journal of Animal Science. 43, 219-228.

Gizaw, S. and Getachew, T. 2009. The Awassi $\times$ Menz Sheep Crossbreeding Project in Ethiopia: Achievements, Challenges and Lessons Learned. Pages 53-62 in Proc. of mid-term conference of the Ethiopian Sheep and Goat Productivity Improvement Program, Achievement, Challenge and Sustainability, Hawassa, Ethiopia.

Gizaw, S., Abegaz, S., Rischkowsky, B., Haile, A., Mwai, A.O. and Dessie, T. (2013). Review of sheep research and development projects in Ethiopia. International Livestock Research Institute (ILRI), Nairobi, Kenya

Gizaw, S., Van Arendonk, J. A. M., Komen, H., Windig, J.J. and Hanotte, O. (2007). Population structure, genetic variation and morphological diversity in indigenous sheep of Ethiopia. Animal genetics. 38, 621628.

Gulilat, L., Walelign, E. and Amane, A. (2018). Evaluation of the Effects of Concentrate Supplementation on Carcass Merits of Farta Sheep. Acad. Res. J. Agri. Sci. Res. 6, 35-41.

Hassen, Y, Solkner, J., Gizaw, S. and Baumung, R. (2002). Performance of crossbred and indigenous sheep under village conditions in the cool highlands of central-northern Ethiopia: growth, birth and body weights. Small Ruminant Research. 43, 195-202.

Hassen, Y., Sölkner, J., and Fuerst-Waltl, B. (2004). Body weight of Awassi and indigenous Ethiopian sheep and their crosses. Small Ruminant Research. 55, 51-56.

Helen, N. (2015). Phenotypic and genetic characterization of indigenous sheep breeds of eastern Ethiopia. PhD dissertation, Haramaya University, Ethiopia.

Kassahun, A. (2000). Comparative performance evaluation of Horro and Menz Sheep of Ethiopia under grazing and intensive feeding condition. $\mathrm{PhD}$ dissertation, Humboldt-University, Germany.

H/Giorgis, K., Alemyehu, A., Jimma, A., Gemeyu, D., Berket, Z. B. and Tera, A. (2017). Productive 
Performance Evaluation of Dorper Sheep and Its F1 at Areka Agricultural Research Centre Mente Dubo Breed Evaluation and Distribution Site Southern Ethiopia. Journal of Biology, Agriculture and Healthcare. 7, 15-21.

Kosgey, I.S., Baker, R.L., Udo, H.M.J. and Var Arendonk, J.A.M. (2006). Successes and failures of small ruminant breeding programs in the tropics: a review. Small Ruminant Research. 61, 13-28.

Kosgey, I.S., Rowlands, G. J., Van Arendonk, J. A. M. and Baker, R. L. (2008). Small ruminant production in smallholder and pastoral/extensive farming systems in Kenya. Small Ruminant Research. 77, 11-24.

Lakew, M., Haile-Melekot, M. and Mekuriaw, G. (2014). Evaluation of Growth Performance of Local and Dorper $\times$ Local Crossbred Sheep in Eastern Amhara Region, Ethiopia', Iranian Journal of Applied Animal Science. 4, 787-794.

Lemma, S., Gizaw, S., Abebe, A. and Getachew, T. (2014). Growth and Reproductive Performance of Menz, Washera $x$ Menz and Bonga x Menz Sheep in the Cool Highlands of Central Ethiopia. Pages173-181 in Proc. of the 6th and 7th Amhara Agricultural Research Institute Annual Regional Conference on Livestock Completed Research, Bahir Dar, Ethiopia.

Markos, T. (2006). Productivity and health of indigenous sheep breeds and crossbreds in the central Ethiopian highlands. PhD dissertation, Swedish University of Agricultural Sciences, Uppsala, Sweden.

Tilahun, M., Deribe, B., Lakew, M., Abreha, S., Belayneh, N., Ayechew, D., Tiruneh, S., Samuel, Menbere, S. and Shenkut, A. (2016). On-farm growth performance of Awassi X Tikur crossbred and Tikur sheep in the Highlands of Eastern Amhara. Pages 177-192 in Proc. of the 9th Amhara Regional Agricultural Research Institute Annual Regional Conference on Livestock Completed Research Activities, Bahir Dar, Ethiopia.

Mekuriaw, S., Mekuriaw, Z., Taye, M., Mekuriaw, G., Amane, A., Bimrew, T. and Haile, A. (2013). Growth performance and linear body measurements of Washera, Farta and their crossbreed sheep under farmer management system in Western Highland of Amhara Region. Scientific Journal of Veterinary Advances. 2, $132-143$.

Philipsson, J., Rege, J.E.O., Zonabend, E. and Okeyo, A.M. (2011). Sustainable breeding programmes for tropical farming systems: Animal Genetics Training Resource version 3, International Livestock Research Institute, Nairobi, Kenya and Swedish University of Agricultural Sciences, Uppsala, Sweden.

Pollott, G. E. and Gootwine, E. (2004). Reproductive Performance and Milk Production of Assaf Sheep in an Intensive Management System. Journal of Dairy Science. 87, 3690-3703.

Schoeman, S. J. (2000). A comparative assessment of Dorper sheep in different production environments and systems. Small Ruminant Research. 36, 137-146.

Shrestha, J. N. B. (2005). Conserving domestic animal diversity among composite populations. Small Ruminant Research. 56, 3-20.

Snyman, M.A. \& Olivier, W. J. (2002). Productive performance of hair and wool type Dorper sheep under extensive conditions. Small Ruminant Research. 45, 17-23.

Solomon, A. (2007). In situ characterization of Gumz sheep under farmer's management in northwestern lowland of Amhara region. MSc thesis, Haramaya University, Ethiopia.

Taye, M, Yitayew, A., Mekuriaw, S. and Bitew, A. (2011). Adaptability and productivity of Washera rams and its crosses with Farta sheep in south Gondar zone of Amhara Region, Ethiopia. Online Journal of Animal and Feed Research. 1, 400-406.

Teklebrhan, T., Urge, M., Mekasha, Y. and Baissa, M. (2014). Pre-weaning growth performance of crossbred lambs (Dorper $\times$ indigenous sheep breeds) under semi-intensive management in eastern Ethiopia. Tropical Animal Health Production. 46, 455-460.

Tilahun, M., Kefelegn, K., Abebe, G. and Goetsch, A.L. (2014). Feed intake, digestibility, weight gain, and slaughter characteristics influenced by genetic percentage of Boer in goats and Dorper in sheep in the central highlands of Ethiopia. Tropical Animal Health Production. 46, 593-602.

Yibrah,Y. (2008). Environmental and genetic parameters of growth, reproductive and survival performance of Afar and Blackhead Somali sheep at Werer Agricultural Research Center, Fellowship report submitted to International Livestock Research Institute (ILRI) and Ethiopian Institute of Agricultural Research (EIAR), Ethiopia.

Zewdu, E. (2008). Characterization of Bonga and Horro indigenous sheep breeds of smallholders for designing community based breeding strategies in Ethiopia. MSc thesis. Haramaya University, Ethiopia. 